\title{
Dialética da História Intelectual
}

Sara Albieri ${ }^{3}$

O título do livro de Alfredo Bosi: Ideologia e contraideologia pode sugerir, à primeira vista, que os temas e variações, anunciados no subtítulo, serão apresentados no modo de um enfrentamento esquemático. Espera-se uma proposta de história intelectual que vá confrontar ideários, representações de interesses, em disputa por uma visão de mundo hegemônica.

O texto se apresenta sem balizas: nenhuma introdução, prefácio ou apresentação; nenhuma carta de intenções antecede suas duas partes. Mesmo saltando às páginas finais, não há conclusão geral que oriente a leitura. O leitor é, pois, sutilmente instado a seguir os meandros das variações que circundam os temas.

Contudo, na Parte I: Perfis e momentos de um conceito, os estudos ali reunidos como notas de trabalho começam com uma breve nota de abertura. Ali o autor evoca a compreensão comum do termo ideologia enquanto construção de ideias e valores, condicionada pelas situações sociais e culturais que a motivam, e, portanto, relativa a elas. Se a inteligência jamais pudesse operar sem tais determinações, então poderia escapar da manipulação e do erro. Mas, desde Platão somos alertados para a ilusão dos sentidos, ou a distorção interessada da verdade, que invariavelmente acompanha o exercício do pensamento. Concisa e um tanto enigmática, a nota de fato propõe a compreensão do termo ideologia de uma nova maneira, aquela que, doravante, será empregada no texto. Com efeito, não se trata de tomar ideologia apenas enquanto produção interessada de representações da verdade, mas também como resultado enganoso do erro e da ilusão; como se ideologia não fosse apenas o efeito perverso de jogos de poder, mas igualmente a consequência das incapacidades humanas. Anuncia-se aí, então, uma história intelectual que avança dialeticamente, visando o conhecimento verdadeiro, entre aproximações e ocultamentos.

A primeira parte do livro destaca temas na história intelectual do ocidente desde a Renascença até a contemporaneidade; e, em cada marco intelectual escolhido, reconhece tanto a afirmação de um ideário como a

3 Sara Albieri é professora livre-docente do Departamento de História da FFLCH/ USP. 
sua crítica. Essa oposição recorrente assume formas diversas: o advento do antropocentrismo na Renascença tem contraponto no relativismo cultural de Montaigne e dos utopistas; o otimismo experimentalista de Francis Bacon é acompanhado pela desconfiança dos ídolos; as certezas cartesianas são desafiadas pelo ceticismo de Pascal e dos moralistas franceses; o liberalismo de Locke e as ideias iluministas são questionados pelas inquietações de Rousseau.

Mas essa polarização também tem vasos comunicantes: o mesmo Bacon que enaltece o experimentalismo alerta para a persuasão dos ídolos; em busca da certeza, Descartes trilha o caminho da dúvida; Locke atribui valor ao trabalho, mas não lhe concede a propriedade dos bens. Aqueles que se propuseram a decifrar as regras do progresso histórico - Vico, Montesquieu, Hegel - também chamam a atenção para seus desvios. O exame dos enfrentamentos revela também as marcas da interlocução.

Finalmente, a conceituação marxista de ideologia lança o dilema para a posteridade: é possível escapar das redes do interesse tecido em ideário, a envolver tanto o que se conserva como a sua crítica? Pois, levado ao extremo, o conceito de ideologia seria uma clausura, sem saída para a busca objetiva da verdade.

$\mathrm{O}$ autor enfrenta o dilema com arguta coragem: a história do conceito de ideologia como distorção está imbricada com aquela - contraideológica - da busca da verdade física ou moral, tanto da natureza como dos homens. O conhecimento se constrói na tensão entre o mascarar e o desvelar, entre o assentamento e o deslocamento, pelo emprego contínuo e crítico das ferramentas da investigação contra as apropriações do interesse.

Os ensaios da Parte II: Intersecções Brasil/Ocidente seguem o diagnóstico dessa tensão fundamental. Eles discutem grandes temas do ideário construído acerca do Brasil, suas circunstâncias de colonização e desenvolvimento, sempre decifrando sentidos a partir da identificação de um enfrentamento ideológico e contraideológico em seus argumentos. Ao final, estendem a mesma orientação analítica à interpretação literária, exemplificada em Machado de Assis.

Em seu conjunto, o livro apresenta uma visão de história intelectual, aquela das obras de pensamento e das ideias. Os estudos históricos relacionados à cultura intelectual e à produção do conhecimento têm sido atribuídos, via de regra, às diferentes áreas de investigação acadêmica, tidos como de sua competência específica. Assim, a história da literatura seria tarefa dos estudiosos das Letras, a da Filosofia, confinada à interpretação dos filósofos, a das ciências, objeto dos cientistas com vocação filosófica ou literária. Ora, o modo como cada área disciplinar concebe a escrita de sua história suscita problemas de teoria e método relacionados 
à pesquisa histórica como um todo. É preciso decidir, por exemplo, se é possível falar de ideias enquanto objeto de investigação histórica, ou se a operação de interpretação de textos pode reivindicar independência dos contextos históricos em que se situam. De modo geral, trata-se de interrogar historicamente as relações, quer práticas ou estruturais, entre produção intelectual, cultura, economia e sociedade.

Na historiografia contemporânea, a explicação da produção intelectual enquanto fenômeno histórico com frequência é remetida às condições externas à obra, sobretudo aquelas sociais e políticas. Com isso se renuncia ao entendimento das razões do texto, para além de suas circunstâncias. Por outro lado, aqueles que eventualmente empreendam uma historiografia que privilegie uma espécie de dinâmica temporal interna ao diálogo entre ideias, dificilmente enfrentam de modo satisfatório as intrincadas relações entre a obra, o autor e o seu tempo.

Este livro oferece um tratamento exemplar dessas questões, mostrando que os caminhos da história intelectual são constituídos dialeticamente. Os temas e problemas são postos a um autor por seu tempo - tecidos no ideário que dá forma ao seu discurso. Mas na elaboração de respostas, assim como no estabelecimento de rumos, as razões do autor podem intervir e moldar o campo das significações sociais que de início as motivaram. É possível, então, enfrentar as determinações do tempo e as injunções da natureza humana na direção de sua superação. A tensão fundamental entre ideologia e contraideologia é, pois, intrínseca à constituição histórica do conhecimento. 